\title{
Cryptogamic epiphytes and microhabitat diversity on non-native green ash (Fraxinus pennsylvanica Marsh., Oleaceae) in urban habitats
}

\author{
Sebastian Dittrich ${ }^{(1)}$, \\ Elke Thiem ${ }^{(1)}$, \\ Birte Marie Albrecht ${ }^{(1)}$, \\ Goddert von Oheimb ${ }^{(1-2)}$
}

\begin{abstract}
With the increased planting of non-native trees within urban environments there is a need for investigating the impacts they may have on the indigenous biodiversity. In this study, we explored the diversity of epiphytic lichens and bryophytes as well as the tree-related microhabitats on planted, non-native green ash Fraxinus pennsylvanica and compared it to that of indigenous Fraxinus excelsior and Quercus robur. We conducted sampling on trees of similar growing conditions and size within two cities of eastern Germany (Dresden and Dessau-Roßlau). In our analysis we did not find any significant differences in epiphyte diversity and abundance. By contrast, microhabitat diversity was significantly higher on $F$. pennsylvanica than on the indigenous tree species, which we attribute to the pioneer character of $F$. pennsylvanica with faster ageing. Our results underline a low impact of $F$. pennsylvanica on epiphytic lichen and bryophyte diversity, while indigenous animals might even benefit from the higher diversity and frequency of microhabitats on trees of this species. Therefore, its use as an ornamental tree should not be generally rejected in urban environments.
\end{abstract}

\section{Keywords: Alien Trees, Bryophytes, Invasiveness, Lichens}

\section{Introduction}

In urban environments, the propagation of non-native (i.e., alien) tree species is indo no longer tolerate the extreme conditions of urban habitats (Roloff et al. 2018 Doroski et al. 2020). As such, non-native tree species might safeguard important tree-related ecosystem services (Dickie et al. 2014). However, some of these species may have serious impacts on indigenous communities, but evidence is rare (Sladonja et al. 2015). Likewise, the potentially beneficial effects are often unknown (Schlaepfer et al. 2011, Litt et al. 2014). This specifically holds true for the impact of non-native trees on epiphytic lichens and bryophytes, a species group that often makes a significant contribution to urban biodiversity (Prather et al. 2018). It has been found that some non-native tree species can support rare epiphyte lichen and dispensable, as many indigenous species bryophyte species and harbour highly diverse epiphyte communities (John \& Stapper 2015, Fudali \& Szymanowski 2019). Though, systematic comparisons to indigenous host tree species in the same habitat are scarce and specifically lacking for urban habitats.

Even fewer data are available for further tree-inhabiting taxa such as fungi and insects (Gossner 2016, Mitchell et al. 2017, Böll 2018). Investigation of these taxa can be difficult, time-consuming and expensive. This is also due to their high species diversity, demand for specialized and rare taxonomic expertise and often inconspicuous, seasonal appearances. Therefore, the trade-off between investigation effort and indicator value of such taxa can be disadsence of direct data on many species groups, tree-related habitat structures have been suggested to serve as a proxy vantageous (Larrieu et al. 2018). In the ab-

(1) Technische Universität Dresden, Institute of General Ecology and Environmental Protection, Chair of Biodiversity and Nature Conservation, Pienner Str. 7, 01735 Tharandt (Germany); (2) German Centre of Integrative Biodiversity Research (iDiv) Halle-Jena-Leipzig, Deutscher Platz 5E, 04103 Leipzig (Germany)

@ Sebastian Dittrich (sebastian.dittrich@tu-dresden.de)

Received: Jan 08, 2021 - Accepted: Jul 06, 2021

Citation: Dittrich S, Thiem E, Albrecht BM, von Oheimb G (2021). Cryptogamic epiphytes and microhabitat diversity on non-native green ash (Fraxinus pennsylvanica Marsh., Oleaceae) in urban habitats. iForest 14: 393-399. - doi: 10.3832/ifor3739-014 [online 2021-09-01] for biodiversity assessments (Paillet et al. 2018). In urban environments microhabitats such as trunk cavities or crown deadwood are critical for many species (Zapponi et al. 2014, Fröhlich \& Ciach 2020). These microhabitats are also supposed to occur on mature and over-aged non-native trees, but evidence is scarce (Zapponi et al. 2014, Bovyn et al. 2019).

Among the trees that are increasingly planted in German cities, North American green ash (Fraxinus pennsylvanica Marsch., Oleaceae), including natural and cultivated varieties, has been proven to be tolerant to harsh environmental conditions (Böll 2018). In addition, F. pennsylvanica is attractive for its appearance. Furthermore, F. pennsylvanica is discussed as an alternative to the indigenous common ash (F. excelsior L.), which is hardly affected by ash dieback (Mitchell et al. 2017). F. pennsylvanica was introduced to some central European countries in the $18^{\text {th }}$ century as an ornamental tree and it was planted in alluvial hardwood forests (Schmiedel et al. 2013). In near-natural habitats of Germany and other European countries this tree species is being considered as invasive (Prots et al. 2011, Nehring et al. 2013, Danielewicz \& Wiatrowska 2014). By contrast, the impact on indigenous epiphytic communities has not yet been assessed in urban habitats of central Europe (but see studies conducted in North America and Eastern Europe - Gallé 1966, 1970, Fojcik \& Stebel 2001, Hyerczyk 2005, Matwiejuk \& Chojnowska 2016), and data for tree-related microhabitats are lacking.

Based on observations in two German 
Tab. 1 - Sample tree features in Dresden and Dessau-Roßlau (mean \pm standard error). (Fp): Fraxinus pennsylvanica; (Fe): Fraxinus excelsior; (Qr): Quercus robur. Statistical testing of the data did not yield significant differences within the relevant study area (Kruskal-Wallis test, Wilcoxon test: $p>0.05$ ).

\begin{tabular}{lcrrrrr}
\hline \multirow{2}{*}{ Feature } & Dresden & \multicolumn{5}{c}{ Dessau-Roßlau } \\
\cline { 2 - 7 } & Fp & Fe & Qr & Fp & Fe & Qr \\
\hline Replicates & 6 & 6 & 6 & 5 & 5 & 5 \\
\hline Bark pH & $5.3 \pm 0.2$ & $5.6 \pm 0.2$ & $5.1 \pm 0.3$ & $5.8 \pm 0.1$ & $5.6 \pm 0.3$ & $5.5 \pm 0.1$ \\
\hline Tree DBH $(\mathrm{cm})$ & $66.2 \pm 6.6$ & $71.4 \pm 9.5$ & $69.3 \pm 9.7$ & $24.9 \pm 2.1$ & $26.9 \pm 3.8$ & $26.2 \pm 4.9$ \\
\hline Site hemeroby & $2.0 \pm 0.2$ & $2.0 \pm 0.2$ & $1.8 \pm 0.2$ & $2.8 \pm 0.2$ & $2.8 \pm 0.2$ & $2.4 \pm 0.2$ \\
\hline
\end{tabular}

cities (namely Dresden and Dessau-Roß lau), this study deals with two questions: (i) Does planted F. pennsylvanica have a negative impact on the diversity of indigenous epiphytic lichens and bryophytes? (ii) Which microhabitats do evolve on planted F. pennsylvanica, compared to indigenous broadleaved tree species?

\section{Material and methods}

Trees were investigated in the cities of Dresden $\left(51^{\circ} 03^{\prime} \mathrm{N}, 13^{\circ} 44^{\prime} \mathrm{E}\right.$ - Saxony Federal State) and Dessau-Roßlau $\left(51^{\circ} 52^{\prime} \mathrm{N}, 12^{\circ}\right.$ $15^{\prime} \mathrm{E}$ - Saxony-Anhalt Federal State) in 2018 and 2019. Climate is characterized as warmtemperate, with mean annual precipitation and mean annual temperature of $650 \mathrm{~mm}$ and $9.0^{\circ} \mathrm{C}$ for Dresden and $542 \mathrm{~mm}$ and 9.2 ${ }^{\circ} \mathrm{C}$ for Dessau-Roßlau for the past decades (Climate-data.org 2020, DWD 2020, Bernhofer et al. 2009). We compared F. pennsylvanica to two indigenous broadleaved tree species which are also common in alluvial hardwood forests in central Europe (Albrecht \& von Oheimb 2018): F. excelsior L. and common oak (Quercus robur L., Fagaceae). Planted F. pennsylvanica individuals were selected based on unpublished in ventories (see Acknowledgments) as well as a public online database on veteran trees ("Champion-Trees" - Gomolka 2017, DDG 2020). The age could not be determined for all individual trees; the oldest $F$. pennsylvanica tree in Dresden (Botanical
Garden) exceeded 130 years (DDG 2020).

For each individual of $F$. pennsylvanica we selected nearby individuals of $F$. excelsior and Q. robur at similar growing conditions and, preferably, similar size (i.e., diameter at breast height, DBH). Therefore, sample trees were not selected randomly and sample tree number was determined by the number of possible species triplets. As a consequence, six replicate groups in Dresden and five replicate groups in DessauRoßlau were established. The Dresden set mainly includes mature and old trees of $\mathrm{DBH}>60 \mathrm{~cm}$, while the sample trees in Dessau-Roßlau are much younger with a $\mathrm{DBH}<40 \mathrm{~cm}$.

Epiphytic lichens and bryophytes were recorded in the lower trunk section of the trees $(0-2 \mathrm{~m})$. Species abundance was quantified by modified percentage estimation referred to the trunk section area covered (Dittrich et al. 2013). For additionally exploring epiphytes in the (often overlooked) tree canopy (Prather et al. 2018) we made use of a peri-urban, over-aged, $F$. pennsylvanica specimen in Dessau-Roßlau, of which large parts of the unstable crown had been cut off and deposited nearby in July 2018. Of a sample tree of $F$. pennsylvanica in Dresden, we could also access downed canopy branches for a survey of canopy-inhabiting epiphyte species. Nomenclature of species is based on Wirth et al. (2013) for lichens, Caspari et al. (2018) for bryophytes and Buttler \& Hand (2008) for vascular plants.

For each tree, we determined the three features $\mathrm{DBH}$, site hemeroby and bark $\mathrm{pH}$ (Tab. 1). DBH was measured with a measuring tape, and we classified hemeroby (i.e., the degree of human impact) of the growing site according to a scale of three classes: class 1 included sites of lowest hemeroby (e.g., abandoned parks and urban successional forests), class 2 represented sites of medium hemeroby (e.g., managed parks and sides of secondary roads), while class 3 included sites of highest hemeroby, i.e., main street roadsides. In the bark pH analyses, $1 \mathrm{~g}$ of sample tree bark was dried and pulverized. Re-hydrated with $20 \mathrm{ml}$ of de-ionised water, these suspensions were horizontally shaken for 24 hours. The $\mathrm{pH}$ values were measured with the electronic analyser Toledo MP-220 (Mettler-Toledo, Greifensee, Switzerland) in the suspension (method after Lüth 2010). Tree-related microhabitats were determined after Kraus et al. (2016), and their presence was noted for each sample tree.

\section{Statistical analyses}

We compared the frequency and mean cover of the epiphyte species as well as the frequency of microhabitats between the three tree species in the two cities. To de tect a significant turnover in species composition between the trees, the epiphyte relevés were subjected to one-way ANOSIM (Clarke 1993) using species abundance ranks for group-wise comparisons. Significant differences in tree features and the single species cover were tested by Kruskal-Wallis test, as the data were not normally distributed (Shapiro-Wilks test, $p$ $<0.05$ ). Differences in microhabitat and species diversity were additionally tested for significance between the sample tree species with the Wilcoxon test. Most statistical analyses were done using the software $R v$. 3.6.3, especially the package " $R$ commander" (R Core Team 2020, Fox 2017), whereas ANOSIM was performed with the software PAST v. 4.01 (Hammer et al. 2001). As climate and growing conditions of the sample tree species in the two regions did not strongly differ, we summarized all sample trees in analyses on the general trends (i.e., $\mathrm{N}=11$ replicates). Detailed epiphyte species composition and microhabitat spectra were analysed separately for the two cities and size classes, respectively.

\section{Results}

In the entire tree set, epiphyte diversity was not significantly different between $F$. pennsylvanica, $F$. excelsior and $Q$. robur (Wilcoxon test, $p>0.05$ - Fig. 1). However, diversity of epiphytic bryophytes was lowest in Q. robur individuals. Trends were similarly expressed in both study areas (Kruskal-Wallis test, $p>0.05$; Wilcoxon test, $p>$ 0.05 - Tab. 2). Furthermore, no significant differences were found in the epiphyte 
Tab. 2 - Epiphyte species (frequency, mean cover \pm standard error) on sample trees in Dresden and Dessau-Roßlau. (Fp): Fraxinus pennsylvanica; (Fe): Fraxinus excelsior; (Qr): Quercus robur; (+): mean cover <0.1\%. Statistical testing of the data did not yield significant differences within the relevant study area and between the sample tree species ( $p>0.05$, Kruskal-Wallis-Test; Wilcoxon test). Rare species: Dresden - Fp: crustose lichen indet., Phlyctis argena, Brachthecium salebrosum, Climacium dendroides, Ptychostomum moravicum, Pylaisia polyantha, Ulota bruchii; Fe: Candellariella aurella, Flavoparmelia soredians, Ptychostomum capillare; Qr: Physcia spec. Dessau-Roßlau - Fp: Candellariella xanthostigma; Fe: Arthonia radiata, Candellariella reflexa; Qr: Candellariella spec., Parmotrema perlatum.

\begin{tabular}{|c|c|c|c|c|c|c|c|c|c|c|c|c|c|}
\hline \multirow{2}{*}{ 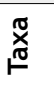 } & \multirow{2}{*}{ Features/Species } & \multicolumn{6}{|c|}{ Dresden } & \multicolumn{6}{|c|}{ Dessau-Roßlau } \\
\hline & & $\mathrm{Fp}$ & & $\mathrm{Fe}$ & & Qr & & $\mathrm{Fp}$ & & $\mathrm{Fe}$ & & Qr & \\
\hline- & Cover lichens & & $11.0 \pm 5.0$ & & $8.5 \pm 2.2$ & & $8.6 \pm 3.6$ & & $31.0 \pm 8.7$ & & $26.4 \pm 10.9$ & & $12.8 \pm 3.1$ \\
\hline- & Cover bryophytes & & $5.3 \pm 3.7$ & & $4.0 \pm 2.1$ & & $0.6 \pm 0.3$ & & $0.4 \pm 0.2$ & & $1.8 \pm 1.0$ & & $0.1 \pm 0.1$ \\
\hline- & Lichen species & & $2.2 \pm 0.6$ & & $3.8 \pm 0.8$ & & $2.8 \pm 0.8$ & & $4.8 \pm 1.0$ & & $4.0 \pm 0.8$ & & $3.6 \pm 0.6$ \\
\hline- & Bryophyte species & & $3.0 \pm 1.3$ & & $2.0 \pm 0.6$ & & $1.2 \pm 0.6$ & & $1.0 \pm 0.4$ & & $2.0 \pm 1.1$ & & $0.2 \pm 0.2$ \\
\hline \multirow{16}{*}{ 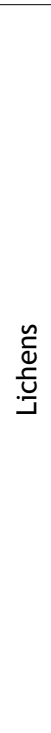 } & Physcia tenella & 33 & $3.4 \pm 3.0$ & 33 & $2.2 \pm 1.5$ & 33 & $0.3 \pm 0.2$ & 100 & $17.8 \pm 7.6$ & 100 & $20.2 \pm 10.8$ & 100 & $10.7 \pm 3.7$ \\
\hline & Xanthoria parietina & 33 & $0.2 \pm 0.1$ & 33 & $0.7 \pm 0.1$ & 33 & $0.2 \pm 0.1$ & 100 & $1.1 \pm 0.3$ & 80 & $1.5 \pm 0.8$ & 80 & $0.6 \pm 1.7$ \\
\hline & Phaeophyscia orbicularis & 17 & $1.3 \pm 1.2$ & 67 & $2.7 \pm 1.5$ & 33 & $6.7 \pm 3.9$ & 60 & $11.0 \pm 7.7$ & 40 & $2.1 \pm 1.8$ & 80 & $1.3 \pm 0.6$ \\
\hline & Candellariella vitellina & - & - & 33 & $0.7 \pm 0.1$ & 17 & $0.1 \pm 0.1$ & 20 & $0.1 \pm 0.1$ & 20 & $0.1 \pm 0.1$ & 20 & $0.1 \pm 0.1$ \\
\hline & Lepraria finckii & 17 & $4.2 \pm 3.8$ & 17 & $1.0 \pm 0.9$ & 33 & $0.2 \pm 0.1$ & 20 & $0.2 \pm 0.2$ & - & - & - & - \\
\hline & Physconia grisea & - & - & 33 & $0.8 \pm 0.6$ & 17 & $0.1 \pm 0.1$ & 20 & $0.1 \pm 0.1$ & 20 & $0.1 \pm 0.1$ & - & - \\
\hline & Amandinea punctata & - & - & 17 & $0.1 \pm 0.1$ & 33 & $0.1 \pm 0.1$ & 40 & $0.2 \pm 0.1$ & 40 & $0.3 \pm 0.2$ & - & - \\
\hline & Lecanora carpinea & 33 & $0.2 \pm 0.1$ & 33 & $0.2 \pm 0.1$ & - & - & 40 & $0.2 \pm 0.1$ & - & - & - & - \\
\hline & Physcia adscendens & 33 & $1.8 \pm 1.5$ & 17 & $0.8 \pm 0.8$ & 17 & $1.7 \pm 1.5$ & - & - & - & - & - & - \\
\hline & Parmelia sulcata & 17 & + & 17 & $0.1 \pm 0.1$ & - & - & 20 & + & - & - & - & - \\
\hline & Cladonia spec. & - & - & 17 & + & 33 & $0.1 \pm 0.1$ & - & - & - & - & - & - \\
\hline & Zwackhia viridis & - & - & 17 & $0.3 \pm 0.3$ & 17 & $0.1 \pm 0.1$ & - & - & - & - & - & - \\
\hline & Lecanora spec. & - & - & 17 & + & - & - & - & - & - & - & 20 & $0.1 \pm 0.1$ \\
\hline & Lecidella elaeochroma & - & - & - & - & - & - & 20 & $0.1 \pm 0.1$ & 40 & $0.9 \pm 0.7$ & 20 & $0.2 \pm 0.2$ \\
\hline & Rinodina pityrea & - & - & - & - & - & - & 20 & $0.1 \pm 0.1$ & 20 & $0.1 \pm 0.1$ & - & - \\
\hline & Masjukiella polycarpa & - & - & - & - & - & - & 20 & + & 20 & $0.1 \pm 0.1$ & - & - \\
\hline \multirow{8}{*}{ 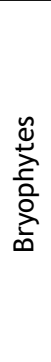 } & Orthotrichum diaphanum & 50 & $0.3 \pm 0.1$ & 33 & $0.2 \pm 0.1$ & - & - & 20 & $0.1 \pm 0.1$ & 40 & $0.2 \pm 0.1$ & 20 & $0.1 \pm 0.1$ \\
\hline & Orthotrichum affine & 33 & $0.7 \pm 0.4$ & 33 & $0.2 \pm 0.1$ & 17 & $0.1 \pm 0.1$ & 40 & $0.2 \pm 0.1$ & 40 & $0.2 \pm 0.1$ & - & - \\
\hline & Hypnum cupressiforme & 50 & $1.5 \pm 1.2$ & 17 & $0.8 \pm 0.8$ & 17 & $0.2 \pm 0.2$ & - & - & 20 & $0.2 \pm 0.2$ & - & - \\
\hline & Brachythecium rutabulum & 33 & $0.6 \pm 0.5$ & 33 & $0.4 \pm 0.3$ & 17 & $0.1 \pm 0.1$ & 40 & $0.2 \pm 0.1$ & - & - & - & - \\
\hline & Platygyrium repens & 17 & $0.5 \pm 0.5$ & 50 & $1.8 \pm 1.5$ & 50 & $0.3 \pm 0.2$ & - & - & 20 & $0.1 \pm 0.1$ & - & - \\
\hline & Amblystegium serpens & 17 & $0.5 \pm 0.5$ & 17 & $0.1 \pm 0.1$ & - & - & - & - & - & - & - & - \\
\hline & Grimmia pulvinata & 17 & + & - & - & - & - & - & - & 20 & $0.1 \pm 0.1$ & - & - \\
\hline & Dicranoweisia cirrata & - & - & - & - & 17 & $0.1 \pm 0.1$ & - & - & 20 & + & - & - \\
\hline
\end{tabular}

community composition (ANOSIM, $p>$ rum chlorococcum - Tab. 2, Tab. 3). 0.05), single tree features and mean cover of the single lichen and bryophyte species (Kruskal-Wallis test, $p>0.05$; Wilcoxon test, $p>0.05)$. These trends were similar both in all sample trees as well as in the different regions and size classes. Few, and rare, lichen or bryophyte species were confined to one tree species in one of the study areas (Tab. 2). Lichen cover and lichen diversity was higher on all sample trees in Dessau-Roßlau, while we observed higher cover and higher diversity of bryophytes in Dresden. The complete epiphyte survey of two F. pennsylvanica specimen revealed a much higher lichen diversity in the tree crown than on the lower trunk. Three epiphyte species found in the canopy of two $F$. pennsylvanica specimen were completely absent from the lower trunk of the other sample trees (Orthotrichum stramineum, Phaeophyscia nigricans, Scoliciospo- higher in F. pennsylvanica than in the two In contrast to the epiphytic species, dif- indigenous tree species in all sample trees ferences in microhabitats were more pro- (Fig. 2) and in Dessau-Roßlau. The same nounced between the three tree species. pattern was found in Dresden, though not Microhabitat diversity was significantly significant (Tab. 4). Additionally, the fre-

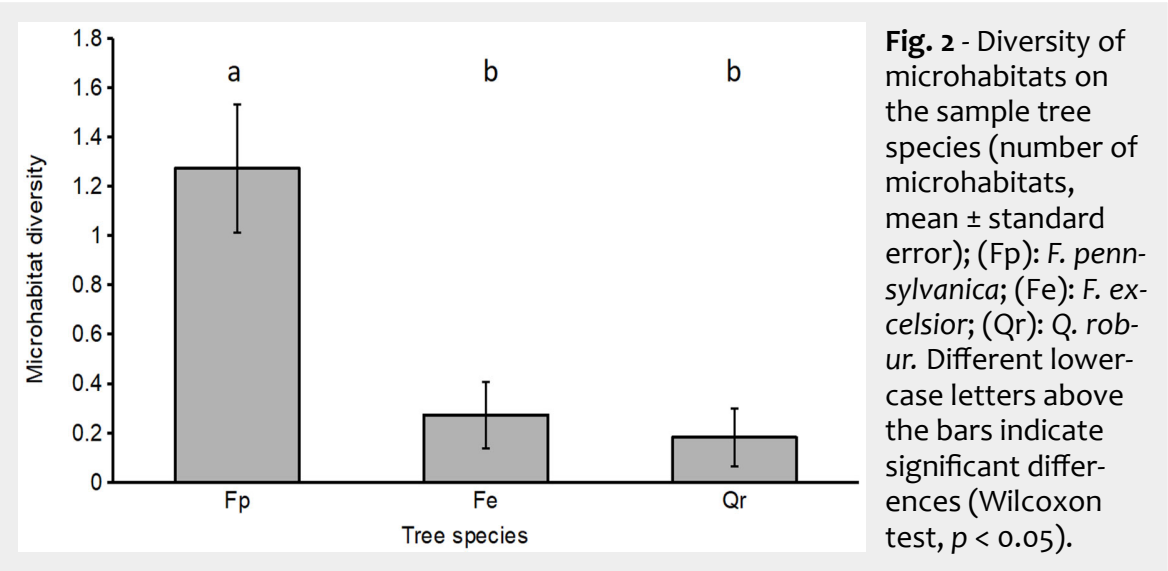


Tab. 3 - Complete, section-wise epiphyte surveys of two $F$. pennsylvanica specimen. (B): bryophytes; (L): lichens; (+): present. (1) Segment division after John \& Stapper (2015): I, 0-40 cm; II, 40-200 cm; III, upper trunk above lowest canopy branch, includes branches $\geq 5 \mathrm{~cm}$ diameter; IV, canopy twigs $<5 \mathrm{~cm}$ diameter; (2) Locations: Dresden, "Bienert-Garten" (successional forest), tree age 123 yrs (DDG 2020); Dessau-Roßlau / Großkühnau, solitary tree on grass lawn; (3): break-off branches surveyed in November 2020.

\begin{tabular}{|c|c|c|c|c|}
\hline \multirow{2}{*}{ Div. ${ }^{(1)}$} & \multirow{2}{*}{ Taxa } & \multirow{2}{*}{ Variable/Species } & \multicolumn{2}{|c|}{ Location $^{(2)}$} \\
\hline & & & Dresden & Dessau-Roßlau \\
\hline \multirow[t]{7}{*}{-} & - & Survey date & Nov $2018^{(3)}$ & July 2018 \\
\hline & & $\mathrm{DBH}(\mathrm{cm})$ & 66 & 73 \\
\hline & & Height (m) & 22 & $>10$ \\
\hline & & Bark pH & 4.75 & 5.9 \\
\hline & & No. Bryophyte species & 5 & 6 \\
\hline & & No. Lichen species & 8 & 4 \\
\hline & & Site hemeroby & 1 & 2 \\
\hline \multirow{2}{*}{1} & B & Brachythecium rutabulum & + & - \\
\hline & B & Hypnum cupressiforme & + & - \\
\hline \multirow{6}{*}{ II } & B & Brachythecium rutabulum & - & + \\
\hline & B & Hypnum cupressiforme & - & + \\
\hline & B & Orthotrichum diaphanum & - & + \\
\hline & L & Phaeophyscia orbicularis & - & + \\
\hline & L & Physcia adscendens & - & + \\
\hline & B & Pylaisia polyantha & - & + \\
\hline \multirow{14}{*}{ III } & B & Orthotrichum affine & + & + \\
\hline & L & Phaeophyscia orbicularis & + & + \\
\hline & L & Xanthoria parietina & + & + \\
\hline & L & Masjukiella polycarpa & + & - \\
\hline & B & Orthotrichum stramineum & + & - \\
\hline & L & Parmelia sulcata & + & - \\
\hline & L & Phaeophyscia nigricans & + & - \\
\hline & L & Physcia tenella & + & - \\
\hline & B & Platygyrium repens & + & - \\
\hline & B & Brachythecium rutabulum & - & + \\
\hline & B & Hypnum cupressiforme & - & + \\
\hline & L & Physconia grisea & - & + \\
\hline & B & Ptychostomum capillare & - & + \\
\hline & B & Pylaisia polyantha & - & + \\
\hline \multirow{8}{*}{ IV } & L & Xanthoria parietina & + & + \\
\hline & L & Candellariella reflexa & + & - \\
\hline & L & Masjukiella polycarpa & + & - \\
\hline & L & Parmelia sulcata & + & - \\
\hline & L & Phaeophyscia orbicularis & + & - \\
\hline & L & Physcia tenella & + & - \\
\hline & L & Scoliciosporum chlorococcum & + & - \\
\hline & L & Physcia adscendens & - & + \\
\hline
\end{tabular}

quency of trees with microhabitats was considerably higher in F. pennsylvanica than in F. excelsior and Q. robur in both cities (Tab. 4). Thereby, mistletoes (Viscum album L.) and different types of crown deadwood were the most frequent microhabitats found in Dresden. In Dessau-Roßlau, microhabitats were even exclusively found on $F$. pennsylvanica. Here, mistletoes and high lichen cover were the only microhabitats present (Tab. 4).

\section{Discussion}

In both cities and the entire dataset of all sample trees, the impact of $F$. pennsylvanica on urban epiphyte diversity was not significant. In contrast to Mitchell et al. (2017) we found that most epiphytes growing on F. excelsior also occurred on F. pennsylvanica and Q. robur. At a low level of acidifying pollution, differences between tree species and even between live and dead trees are generally less pronounced (Bates \& Brown
1981, Hauck 2005). While the abundance of some lichens can strongly shift due to slight variations in bark $\mathrm{pH}$ (Hauck et al. 2011), the ecological amplitude of many other epiphyte species enables their colonization even of trees with strongly different bark chemistry and structure (Bates \& Brown 1981, Mitchell et al. 2021). Therefore, the small bark $\mathrm{pH}$ variations in both cities across the three tree species did not affect epiphyte community composition either, as well as their naturalization status (Mitchell et al. 2021).

Few epiphyte species preferably occurred on one tree species. Based on the total number of epiphytic lichen species, however, a cross-regional comparison between different cities and host-trees points to larger differences between the tree species but also to a high variation across the different study areas (Tab. 5). Such results, including our own study, support the findings of Richter et al. (2009) that the importance of different host tree species for epiphyte diversity also depends on the surrounding local habitat or urban landscape type. Besides, none of the available previous studies provided detailed information on the age and number of the tree specimens studied, which might contribute to the different local diversity patterns (Tab. 5).

Some additional species found in the canopy of two F. pennsylvanica trees also point on an incomplete epiphyte assessment by our trunk-based investigation, at least in Dresden. But this methodical limitation applies to all sampled trees included in the comparison. Furthermore, species confined to the tree canopy in closed forests can be expected to occur at lower trunk sections of tree individuals outside forests (Wirth et al. 2009). This is also substantiated by the different vertical epiphyte stratification on the two completely surveyed trees at different growing conditions (Tab. 3). Therefore, the share of neglected epiphyte species in urban areas may be lower than in closed forest stands (Boch et al. 2013). Consequently, surveys of the lower tree trunk sections can be sufficient for analyses of the diversity and indicator value of cryptogamic epiphytes in urban areas (Prather et al. 2018).

Most of the lichen and bryophyte species found can be classified as pollution-tolerant, i.e., toxitolerant, acidophytic or nitrophytic (Dierßen 2001, Wirth et al. 2013). They are common in settlement areas and have partly been found in previous studies on urban F. pennslyvanica in Eastern Europe (Gallé 1966, 1970, Fojcik \& Stebel 2001, Matwiejuk \& Chojnowska 2016). Locally noteworthy are Climacium dendroides and Zwackhia viridis, which rarely occur in urban areas and are confined to the larger trees in Dresden (Tab. 2). Rarely found Flavoparmelia soredians and Parmotrema perlatum indicate climate warming (VDI 2017). Much more than host tree identity, the epiphytes found depict the imprint of 
Tab. 4 - Frequency (\%) of microhabitats found on the sample trees in the two cities (classification and coding after Kraus et al. 2016). (Fp): F. pennsylvanica; (Fe): F. excelsior; ( $\mathrm{Qr}$ ): Q. robur. Different lower-case letters indicate significant differences in the microhabitat diversity within the relevant study area (Wilcoxon test, $p<0.05$ ).

\begin{tabular}{|c|c|c|c|c|c|c|c|}
\hline \multirow{2}{*}{ Feature } & \multicolumn{3}{|l|}{ Dresden } & \multicolumn{3}{|c|}{ Dessau-Roßlau } & \multirow{2}{*}{ Code } \\
\hline & $\mathrm{Fp}$ & $\mathrm{Fe}$ & Qr & $\mathrm{Fp}$ & $\mathrm{Fe}$ & Qr & \\
\hline$\%$ sample trees with microhabitats & 83 & 50 & 33 & 60 & 0 & 0 & - \\
\hline Diversity of microhabitats & $1.5 \pm 0.4^{\mathrm{a}}$ & $0.5 \pm 0.2^{\mathrm{a}}$ & $0.3 \pm 0.2^{\mathrm{a}}$ & $1.0 \pm 0.3^{\mathrm{a}}$ & $0^{b}$ & $0^{b}$ & - \\
\hline Mistletoe (Viscum album) & 50 & - & - & 40 & - & - & EP35 \\
\hline Trunk cavity with ground contact & 33 & 17 & - & - & - & - & CV21 \\
\hline Dead branches / crown deadwood & 33 & - & 17 & - & - & - & $\mathrm{DE} 11+\mathrm{DE} 13$ \\
\hline Small trunk cavities & 17 & 17 & - & - & - & - & $\mathrm{CV} 13+\mathrm{CV} 22$ \\
\hline Annual polypores (cf. Laetiporus spec.) & 17 & - & - & - & - & - & EP11 \\
\hline Small vertebrate nest (songbird) & 17 & - & - & - & - & - & NE12 \\
\hline Branch hole / rot hole & - & 17 & - & - & - & - & CV31 \\
\hline Gallery of bore holes (cf. Hylesinus fraxini) & - & 17 & - & - & - & - & CV51 \\
\hline Liana cover >25\% (Hedera helix) & - & - & 17 & - & - & - & EP33 \\
\hline Epiphytic foliose lichen cover $>25 \%$ & - & - & - & 60 & - & - & EP32 \\
\hline
\end{tabular}

Tab. 5 - Number of lichen species on the investigated host tree species in different cities of Europe and North America. (Total): entire lichen species on the three sample tree species; (Fp): F. pennsylvanica; (Fe): F. excelsior; (Qr): Q. Robur; (1): based on the description of the investigated sites; (2): F. pennsylvanica only in one location; (3): F. pennsylvanica included F. p. var. subintegerrima; F. excelsior: F. excelsior "Hessei”; no specimens of Q. robur.

\begin{tabular}{lcrrrrl}
\hline City & Total & Fp & Fe & Qr & $\begin{array}{c}\text { Site } \\
\text { hemeroby }{ }^{(1)}\end{array}$ & Reference \\
\hline Lomza (PL) & 24 & 3 & 24 & 11 & $2-3$ & Matwiejuk \& Chojnowska (2016) \\
\hline Szarvas (HUN) & 20 & 6 & 11 & 11 & 2 & Gallé (1970) \\
\hline Dresden (D) & 19 & 9 & 15 & 11 & $1-3$ & This study \\
\hline Dessau-Roßlau (D) & 18 & 13 & 11 & 8 & $2-3$ & This study \\
\hline Chicago (USA) & 16 & 15 & 7 & - & 2 & Hyerczyk (2005) $^{(3)}$ \\
\hline Szeged (HUN) & 10 & 7 & 5 & 3 & 2 & Gallé (1966) $^{(3)}$ \\
\hline
\end{tabular}

(past) pollution, together with recent eutrophication and over-warming of urban areas. These factors lead to both impoverishment and homogenization of epiphyte communities (Stapper \& John 2015, Liška \& Herben 2008).

While epiphytic lichens and bryophytes were documented by direct surveys in this study, the possible occurrences of other taxa can be estimated from structural tree attributes (Paillet et al. 2018). So far, the higher frequency and significantly higher diversity of microhabitats found on urban F. pennsylvanica compared to the two indigenous tree species (Fig. 2) points to a certain ecological significance for treebound biota. The (overall) higher microhabitat diversity on sample trees in Dresden than in Dessau-Roßlau can mainly be attributed to their larger dimensions and, thus, higher age (Paillet et al. 2019).

In comparison to the two indigenous tree species, the higher frequency and diversity of microhabitats may be due to the pioneer character and shorter life span of $F$. pennsylvanica (125-150 yrs - Schmiedel 2011). This could lead to faster ageing and more timely creation of microhabitats compared to the intermediate $F$. excelsior and the long-lived Q. robur. This is also substan- tiated by the results for Dessau-Roßlau. Here, among the younger-aged sample trees, only F. pennsylvanica had evolved any microhabitats at all. Within the Dresden dataset, microhabitat frequency and diversity was higher in $F$. pennsylvanica (though not statistically significant in the case of microhabitat diversity) than on the two indigenous tree species.

However, data on indigenous animal species which actually use such microhabitats on F. pennsylvanica in general, are widely lacking (Mitchell et al. 2017). In Dresden, we at least encountered an active wasp hive in a trunk cavity of $F$. pennsylvanica and a bird nest on twigs. The aforementioned over-aged $F$. pennsylvanica specimen in Dessau-Roßlau (Tab. 3) had a hollow trunk and accommodated a Hornet hive (Vespa cabro L.) in 2017. On declining specimen in Dresden, not included in the sampling, we observed woodpecker holes (Dendrocopus major L.). In central German alluvial hardwood forests, F. pennsylvanica is also used by several cave-nesting bird species (Krause et al. 2008). However, in alluvial hardwood forests, indigenous taxa might yet use indigenous trees to a disproportionately higher degree than non-native tree species (Smith \& Finch 2014).

\section{Conclusions}

Our study provides evidence on a low impact of the non-native tree species F. pennsylvanica on the diversity of epiphytic lichens and bryophytes in urban habitats, when compared to the two common indigenous tree species F. excelsior and Q. robur. The higher frequency of tree-related microhabitats, with significantly higher microhabitat diversity found for F. pennsylvanica compared to the two indigenous tree species, could even be potentially beneficiary to the urban fauna. Therefore, in contrast to near-natural habitats of high conservation value such as alluvial hardwood forests, the use of $F$. pennsylvanica as ornamental tree in urban environments of central Europe should not be generally rejected. However, cross-regional conclusions are limited and further research should focus on its interaction with other taxonomic groups. The spontaneous establishment and potential spread of F. pennsylvanica in urban environments and beyond should, nonetheless, be monitored and managed.

\section{Acknowledgements}

Field work in Dessau-Roßlau was funded by a grant from the German Federal Insti- 
tute of Hydrology (Bundesanstalt für Gewässerkunde, BfG) within the project "The impact of Fraxinus pennsylvanica on the biodiversity of River Elbe and River Oder". Christian Bodamer (city administration, Dessau-Roßlau) and Steffen Löbel (city administration, Dresden) provided data on planted $F$. pennsylvanica and other sample trees. Barbara Ditsch granted access to Dresden botanical garden for epiphyte assessments. Laboratory analyses were done at the Institute of Soil Science and Site Ecology (Forestry, TU Dresden). Klaus Max Stetzka (Institute of Forest Zoology and Forest Botany, TU Dresden) checked some critical lichen samples.

\section{References}

Albrecht BM, von Oheimb G (2018). Erste Ergebnisse zum Einfluss der Rot-Esche auf die Biodiversität an der Elbe [First results on the impact of green ash on the biodiversity at the river Elbe]. Naturschutz im Land Sachsen-Anhalt 55 Sonderheft: 87-91. [in German]

Bates JW, Brown DH (1981). Epiphyte differentiation between Quercus petraea and Fraxinus excelsior trees in a maritime area of South West England. Vegetatio 48: 61-70. - doi: 10.1007/BF 00117362

Bernhofer C, Matschullat J, Bobeth A (2009). Das Klima in der REGKLAM-Modellregion Dresden [Climate in the REGKLAM model region Dresden]. RHOMBOS-Verlag, Berlin, Germany, pp. 117. [in German]

Boch S, Müller J, Prati D, Blaser S, Fischer M (2013). Up in the tree - The overlooked richness of bryophytes and lichens in tree crowns. PLoS One 8 (12): e84913. - doi: 10.1371/journal.pone. 0084913

Böll S (2018). Stadtbäume der Zukunft - Wichtige Ergebnisse aus dem Forschungsprojekt "Stadtgrün 2021" [Future urban trees - Important results of the research project "Stadtgrün 2021"]. Veitshöchheimer Berichte 184: 75-85. [in German]

Bovyn RA, Lordon MC, Grecco AE, Leeper AC, LaMontagne JM (2019). Tree cavity availability in urban cemeteries and city parks. Journal of Urban Ecology 5 (1): 139. - doi: 10.1093/jue/juy030 Buttler KP, Hand R (2008). Liste der Gefäßpflanzen Deutschlands [List of vascular plants of Germany]. Kochia, Beiheft 1: 1-107. [in German]

Caspari S, Dürhammer O, Sauer $M$, Schmidt C (2018). Rote Liste und Gesamtartenliste der Moose (Anthocerotophyta, Marchantiophyta und Bryophyta) Deutschlands [Red list and total species list of german bryophytes]. Naturschutz und Biologische Vielfalt 70 (7): 361-489. [in German]

Clarke KR (1993). Nonparametric multivariate analyses of changes in community structure. Australian Ecology 18: 117-143. - doi: 10.1111/j.144 2-9993.1993.tboo438.x

Climate-data.org (2020). Daten und Graphen zum Klima und Wetter für Dessau-Roßlau [Data and graphs on climate and weather for DessauRoßlau]. Website. [in German] [online] URL: http://de.climate-data.org/europa/deutschland/ sachsen-anhalt/dessau-rosslau-22429/\#climatetable
Danielewicz W, Wiatrowska B (2014). Inwazyjne gatunki drzew i krzewów w lasach Polski [The most invasive tree and shrub species in Polish forests]. Peckiana 9: 59-67. [in Polish]

DDG (2020). Rekordbäume [Champion-Trees]. Website. [in German] [online] URL: http:// www.ddg-web.de/index.php/rekordbaeume.ht $\mathrm{ml}$

Dickie IA, Bennett BM, Burrows LE, Nuñez MA, Peltzer DA, Porté A, Richardson DM, Rejmánek M, Rundel PW, Van Wilgen BW (2014). Conflicting values: ecosystem services and invasive tree management. Biological Invasions 16: 705719. - doi: 10.1007/s10530-013-0609-6

Dierßen K (2001). Distribution, ecological amplitude and phytosociological characterization of European bryophytes. Bryophytorum Bibliotheca 56, pp. 289. [online] URL: http://www. schweizerbart.de/publications/detail/isbn/9783 443620288

Dittrich S, Hauck M, Jacob M, Rommerskirchen A, Leuschner C (2013). Response of ground vegetation and epiphyte diversity to natural age dynamics in a Central European mountain spruce forest. Journal of Vegetation Science 24: 675-687. - doi: 10.1111/j.1654-1103.2012.01490.x Doroski DA, Ashton MS, Duguid MC (2020). The future urban forest - A survey of tree planting programs in the Northeastern United States. Urban Forestry and Urban Greening 55: 126816. doi: 10.1016/j.ufug.2020.126816

DWD (2020). Niederschlag: vieljährige Mittelwerte 1971-2000 [Precipitation: long-term mean 1971-2000]. Website. [in German] [online] URL: http://www.dwd.de/DE/leistungen/klimadatend eutschland/mittelwerte/nieder_7100_fest_htm l.html

Fojcik B, Stebel A (2001). Struktura ekologiczna i przestrzenna brioflory miasta Katowice [Ecological and spatial structure of bryoflora of Katowice town]. Materialy Opracowania Centrum Dziedzictwa Przyrody Górnego Slaska w Katowicach 5: 1-128. [in Polish]

Fox $J$ (2017). Using the R Commander: a pointand-click interface for R. Chapman and Hall/CRC Press, Boca Raton, FL, USA, pp. 213.

Fröhlich A, Ciach M (2020). Dead tree branches in urban forests and private gardens are key habitat components for woodpeckers in a city matrix. Landscape and Urban Planning 202: 103869. - doi: 10.1016/j.landurbplan.2020.1038 69

Fudali E, Szymanowski M (2019). Epiphytic bryophytes on alien host-tree species in Wroclaw (SW Poland). Cryptogamie Bryologie 40: 117129. - doi: 10.5252/cryptogamie-bryologiezo19v4 oa11

Gallé L (1966). Lichen flora of the forty years old botanical garden in Szeged. Tiscia 2: 41-46. [online] URL: http://acta.bibl.u-szeged.hu/9633/1/ti scia_002_041-046.pdf

Gallé $L$ (1970). Die Flechtenvegetation und Flechtenzönosen des Arboretums in Szarvas [Lichen vegetation and lichen communities of the Szarvas arboretum]. Acta Biologica Szeged 16: 43-49. [in German]

Gomolka A (2017). Das Projekt Rekordbäume / Champion-Trees in Deutschland [The project "Record master trees / Champion-Trees in Germany]. DDG-Mitteilungen 102: 261-269. [online] URL: http://www.treehunter.de/en/publications
/MDDG-102_Das-Projekt-Championtrees.pdf Gossner MM (2016). Introduced tree species in central Europe - Consequences for arthropod communities and species interactions. In: "Introduced Tree Species in European Forests: Opportunities and Challenges" (Krumm F, Vítková L eds). European Forest Institute, Freiburg, Germany, pp. 264-282. [online] URL: http://www.re searchgate.net/publication/311229246

Hammer O, Harper DAT, Ryan PD (2001). PAST: Paleontological statistics software package for education and data analysis. Palaeontologia Electronica 4 (1): 9. [online] URL: http://paleo. carleton.ca/2001_1/past/past.pdf

Hauck M (2005). Epiphytic lichen diversity on dead and dying conifers under different levels of atmospheric pollution. Environmental Pollution 135: 111-119. - doi: 10.1016/j.envpol.2004.09. 021

Hauck M, Otto PI, Dittrich S, Jacob M, Bade C, Dörfler I, Leuschner C (2011). Small increase in substratum $\mathrm{pH}$ causes the dieback of one of Europe's most common lichens, Lecanora conizaeoides. Annals of Botany 108: 359-366. - doi: 10.1093/aob/mcr136

Hyerczyk RD (2005). The lichen flora of ten Chicago parks, Chicago Park District, Chicago, Illinois. Transactions of the Illinois State Academy of Science 98: 97-122. [online] URL: http://ilacadofsci.com/wp-content/uploads/2013 /04/098-12MS2422-print.pdf

John V, Stapper NJ (2015). Schwarznuss (Juglans nigra) in Auwäldern am Rhein als bedeutender Trägerbaum für Flechten und Moose in Rheinland-Pfalz [Black walnut (Juglans nigra) in riparian forests along the Rhine valley as an important phorophyte for lichens and bryophytes in Rheinland-Pfalz]. Herzogia 28: 405-429. [in German] - doi: 10.13158/heia.28.2.2015.405

Kraus D, Bütler R, Krumm F, Lachat T, Larrieu L, Mergner U, Paillet $Y$, Rydkvist T, Schuck A, Winter S (2016). Katalog der Baummikrohabitate Referenzliste für Feldaufnahmen [Catalogue of tree microhabitats - Reference fieldlist]. Technical Paper, Integrate+, German Federal Ministry of Food and Agriculture - BMEL, Bonn, Germany, pp. 16. [in German]

Krause U, Patzak U, Eichhorn A (2008). Nischenstruktur und Vogelbesiedlung von Roteschenbeständen auf feuchten Auenstandorten [Niche structure and bird colonization of green ash stands at moist alluvial sites]. Veröffentlichungen LPR Landschaftsplanung Dr. Reichhoff $\mathrm{GmbH}$ 4: 47-53. [in German]

Larrieu L, Gosselin F, Archaux F, Chevalier R, Corriol G, Dauffy-Richard E, Deconchat M, Gosselin M, Ladet S, Savoie J-M, Tillon L, Bouget C (2018). Cost-efficiency of cross-taxon surrogates in temperate forests. Ecological Indicators 87: 56-65. - doi: 10.1016/j.ecolind.2017.12. 044

Liška J, Herben T (2008). Long-term changes of epiphytic lichen species composition over landscape gradients: an 18 year time series. The $\mathrm{Li}$ chenologist 40: 437-448. - doi: 10.1017/So02428 2908006610

Litt AR, Cord EE, Fulbright TE, Schuster GL (2014). Effects of invasive plants on Arthropods. Conservation Biology 28: 1532-1549. - doi: 10.1111/cobi.12350

Lüth M (2010). Ökologie und Vergesellschaftung 
von Orthotrichum rogeri [Ecology and phytosociology of Orthotrichum rogeri]. Herzogia 23: 121-149. [in German] - doi: 10.13158/heia.23.1.20 10.121

Matwiejuk A, Chojnowska P (2016). Lichens of Lomza town (Podlasie, North-Eastern Poland). Steciana 20: 53-62. - doi: 10.12657/steciana.020. 007

Mitchell RJ, Broome A, Beaton JK, Bellamy PE, Ellis $C J$, Hester AJ, Hodgetts NG, lason GR, Littlewood NA, Newey S, Pozsgai G, Ramsay S, Riach D, Stockan JA, Taylor AFS, Woodward S (2017). Challenges in assessing the ecological impacts of tree diseases and mitigation measures: the case of Hymenoscyphus fraxineus and Fraxinus excelsior. Baltic Forestry 23: 116-140. [online] URL: http://pure.sruc.ac.uk/en/publica tions/challenges-in-assessing-the-ecological-im pacts-of-tree-diseases-a

Mitchell RJ, Hewison RL, Beaton J, Douglass JR (2021). Identifying substitute host tree species for epiphytes: the relative importance of tree size and species, bark and site characteristics. Applied Vegetation Science 24: e12569. - doi: 10.1111/avsc.12569

Nehring S, Kowarik I, Rabitsch Essl W (2013). Naturschutzfachliche Invasivitätsbewertungen für in Deutschland wild lebende gebietsfremde Gefäßpflanzen [Classification of the invasiveness of wild, non-native, vascular plants in Germany with regard to nature conservation]. BfNSkripten 352, pp. 202. [in German] [online] URL: http://www.researchgate.net/publication/2584 76200

Paillet Y, Archaux F, Puy S, Bouget C, Boulanger V, Debaive N, Gilg O, Gosselin F, Guilbert E (2018). The indicator side of tree microhabitats: a multi- taxon approach based on bats, birds and saproxylic beetles. Journal of Applied Ecology 55: 2147-2159. - doi: 10.1111/1365-2664.13181 Paillet Y, Debaive N, Archaux F, Cateau F, Gilg O, Guilbert E (2019). Nothing else matters? Tree diameter and living status have more effects than biogeoclimatic context on microhabitat number and occurrence: an analysis in French forest reserves. PLoS One 14 (5): e0216500. doi: 10.1371/journal.pone.0216500

Prather HM, Eppley SM, Rosenstiel TN (2018). Urban forested parks and tall tree canopies contribute to macrolichen epiphyte biodiversity in urban landscapes. Urban Forestry and Urban Greening 32: 133-142. - doi: 10.1016/j.ufug. 2018.04.012

Prots B, Drescher A, Vykhor B (2011). Invasion ecology of Green Ash Fraxinus pennsylvanica Marsh. in the Transcarpathia (Ukraine). Journal of Biological Systems 3: 269-276.

$R$ Core Team (2020). R: a language and environment for statistical computing. R Foundation for Statistical Computing, Vienna, Austria. [online] URL: http://www.r-project.org

Richter S, Schütze P, Bruelheide H (2009). Untersuchungen zu Flora und Vegetation der epiphytischen Moose in Halle/Saale (Sachsen-Anhalt) [Study of the flora and vegetation of epiphytic bryophytes in Halle/Saale (Saxony-Anhalt)]. Hercynia NF 42: 177-195. [in German] [online] URL: http://public.bibliothek.uni-halle.de/ index.php/hercynia/article/view/1684

Roloff A, Gillner S, Kniesel R, Zhang D (2018). Interesting and new street tree species for European cities. Journal of Forest and Landscape Research 1: 1-7. - doi: 10.13141/jflr.v3i1.1995

Schlaepfer MA, Sax DF, Olden J (2011). The potential conservation value of non-native species. Conservation Biology 25: 428-437. - doi: 10.1111/j.1523-1739.2010.01646.x

Schmiedel D (2011). Fraxinus pennsylvanica Marschall, 1785. In: "Enzyklopädie der Holzgewächse: Handbuch und Atlas der Dendrologie" (Schütt P, Schuck HJ, Aas G, Lang U eds). Wiley, Suppl. 57 (3/2011), pp. 1-12. [in German] [online] URL: http://onlinelibrary.wiley.com/do i/epdf/10.1002/9783527678518.ehg2011004

Schmiedel D, Huth F, Wagner S (2013). Using data from seed-dispersal modelling to manage invasive tree species: the example of Fraxinus pennsylvanica Marshall in Europe. Environmental Management 52: 851-860. - doi: 10.1007/so 0267-013-0135-4

Sladonja B, Sušek M, Guillermic J (2015). Review on invasive Tree of Heaven (Ailanthus altissima (Mill.) Swingle). Conflicting values: assessment of its ecosystem services and potential biological threat. Environmental Management 56: 1009-1034. - doi: 10.1007/s00267-015-0546-5

Smith DM, Finch DM (2014). Use of native and nonnative nest plants by riparian-nesting birds along two streams in New Mexico. River Research and Applications 30: 1134-1145. - doi: 10.1002/rra.2713

Stapper NJ, John V (2015). Monitoring climate change with lichens as bioindicators. Pollution Atmosphérique 226: 1-12. [online] URL: http:// lodel.irevues.inist.fr/pollution-atmospherique/i ndex.php?id=4936

VDI (2017). VDI standard 3957 Part 20: biological measuring techniques for the determination and evaluation of effects of air pollutants (biomonitoring). Mapping of lichens to indicate local climate change. Verein Deutscher Ingenieure - VDI, Berlin, Germany, pp. 35.

Wirth $V$, Hauck M, De Bruyn U, Schiefelbein U, John V, Otte V (2009). Flechten aus Deutschland mit Verbreitungsschwerpunkt im Wald [Lichens typically occurring in forests of Germany]. Herzogia 22: 79-107. [in German] [online] URL: http://blam-bl.de/images/Herzogia_ 22/Downloads/H22-Wirth_et_al.pdf

Wirth V, Hauck M, Schultz M (2013). Die Flechten Deutschlands [Lichens of Germany]. Ulmer Verlag, Stuttgart, Germany, vol. 1+2, pp. 1244.

Zapponi L, Minari E, Longo L, Toni I, Mason F, Campanaro A (2014). The Habitat-Trees experiment: using exotic tree species as new microhabitats for the native fauna. iForest 8: 464470. - doi: 10.3832/ifor1281-007 